\title{
Dual-Axis Solar Tracking System Efficiency for Hydroponics Pump
}

\author{
Fitria Hidayanti $^{1}$, Fitri Rahmah ${ }^{2}$, Malika Ikrimah ${ }^{2}$ \\ ${ }^{1}$ Engineering Physics Department, Universitas Nasional, Jakarta 12520 Indonesia, fitriahidayanti@gmail.com \\ ${ }^{2}$ Engineering Physics Department, Universitas Nasional, Jakarta 12520 Indonesia
}

\begin{abstract}
The advancement of solar power technology is considered one of many choices for meeting the increasing demand for energy worldwide. Solar energy is radiant light, and use of heat from the sun using technology such as photovoltaic technology which involves the use of semiconductors to directly convert sunlight into electrical energy has become a highly desirable choice. The electrical energy generated by a device for generating photovoltaic power can be used for a wide range of applications. A solar tracking system is the most appropriate technology for enhancing the solar cells performance by tracking the sun. Solar cell with a capacity of $50 \mathrm{Wp}$ solar and battery $7 \mathrm{Ah}$. Tests conducted for five days, each day of the test starting from06:00 AM to 06:00 PM andusing fourlight dependent resistor (LDR) sensor to track the sun by calculating the highest intensity. Experimental results show that the intensity-based dual-axis tracking system improves the overall efficiency.
\end{abstract}

Key words : Solar Energy, Dual-Axis, Tracking, System, Light Dependent Resistor

\section{INTRODUCTION}

Electrical energy is energy that is needed by humans in carrying out daily activities, and electrical energy is an integral part of supporting human life[1-3]. Electricity is one of the primary needs of the community, including in rural areas [4]. In recent years, the need for energy is increasing many folds, while the reserves of conventional energy are getting depleted at a rapid pace [5-7]. Fossil fuel resources are limited, and their use contributes to global warming due to green house gas emissions. Various studies are now leading to the development of alternative sources of energy, such as nuclear, solar, water, wind, biomass, geothermal and ocean wave energy [8-12].

Besides being renewable, alternative energy sources are environmentally friendly energy sources (green energy) because they do not cause pollution, except nuclear energy [13]. A solar cell is a technology of utilizing solar energy by converting that energy into an electric current using a semiconductor device called a solar cell [13, 14]. Most solar cells are installed permanently with fixed elevating angles or commonly called static solar cells $[15,16]$. These cause the solar cell can not absorb solar radiation optimally because the sun still travels in the east - west direction (called the pseudo-daily movement of the sun) and in the north - south direction (called the annual pseudo-solar movement). If the direction of solar radiation is perpendicular to the solar cell field surface, the absorption of solar radiation will be optimum. Therefore it takes an effort to guide the solar surface so that it is always perpendicular to sunlight. The method for directing the solar cell so that it always follows the direction of solar motion is known as the method of tracking the sun's direction [13].

\section{MATERIALS AND METHOD}

\section{Block Diagram System}

The tracker detects direct solar radiation falling on photo-sensors as a feedback signal to ensure the sun is always monitored by the photovoltaic (PV) panel. Because of their ability to follow the sun vertically and horizontally, dual-axis trackers require maximum solar energy levels.

The dual-axis tracker works in the same way as the single axis. It is just a dual-axis tracker measuring the horizontal axis and vertical axis. The average power value proves that solar cell with dual-axis produces more power than static solar. The power efficiency calculated for the dual-axis tracker is said to be $25 \%$ higher than static solar cell $[17,18]$.

A solar tracker is a control circuit to regulate motor movements so that the sun's intensity received by the optimum solar cell. This happens when the solar cell board controls the direction of the sun continuously. In the morning the servo motor will move from east to west following the sun's direction based on 4 LDRs. In addition to moving horizontally from east to west, the solar tracker also follows the high position of the sun's angle in the sky, known as the dual-axis tracking method. Power output for a solar cell with dual-axis tracker and static solar cell tabulated for a day.

Figure 1 shows the system implementation in its experimental results that validate the proper operation of the system. 


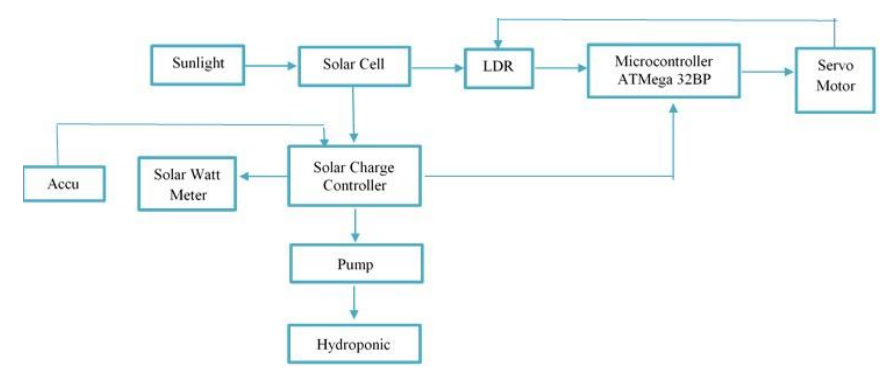

Figure 1: Block Diagram System

The solar tracker block diagram was shown in Figure 1. The main components of this system are LDR sensors, microcontrollers, servo motors, solar cells, and batteries. When sunlight hits the LDR sensor, the servo motor will be active. The sensor gives input to the microcontroller and from the microcontroller directly gives a command on the servo motor that will move the solar cell always to be perpendicular to the direction of the arrival of sunlight. The solar cell receives sunlight and then converts it into electrical energy by the solar cell. The electrical energy produced is stored in batteries for hydroponic purposes.

\section{RESULTS AND DISCUSSION}

Solar tracking mechanism is a critical factor in increasing power generation output by solar panel. The concept of the mechanical solar tracking system requires a motor to ensure that the PV panel is positioned correctly during the day regarding the sun position.The complete display of dual-axis solar tracker is shown in Figure 2. as a drive for the horizontal rotating axis. The bottom is the base of the tool.

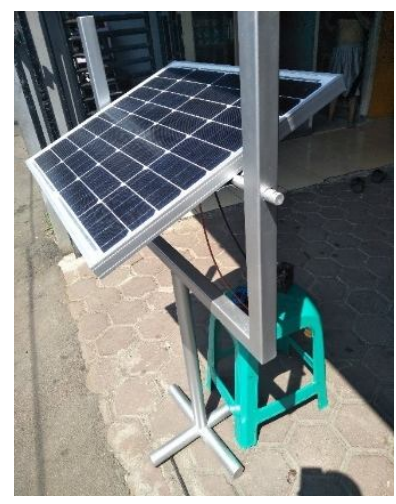

Figure 2: The Display of Dual-Axis Tracking System

The solar panel kept in the fixed position and the performance of the solar panel tested from 06:00 AM to 06:00 PM. This test is to determine the amount of voltage, current, and power obtained when the solar cell is fixed angle position $45^{\circ}$ and then compare the results obtained with a solar tracker. Static solar cell testing is carried out for five days. Data retrieval recorded every hour.

Solar tracker being tested by almost the same as static solar cell testing. The solar cell test equipped with a servo motor and microcontroller with programs and algorithms that have been designed to find at the highest intensity of sunlight. The comparative results of the performance curve of static solar cell and solar tracker shown in Figure 3.

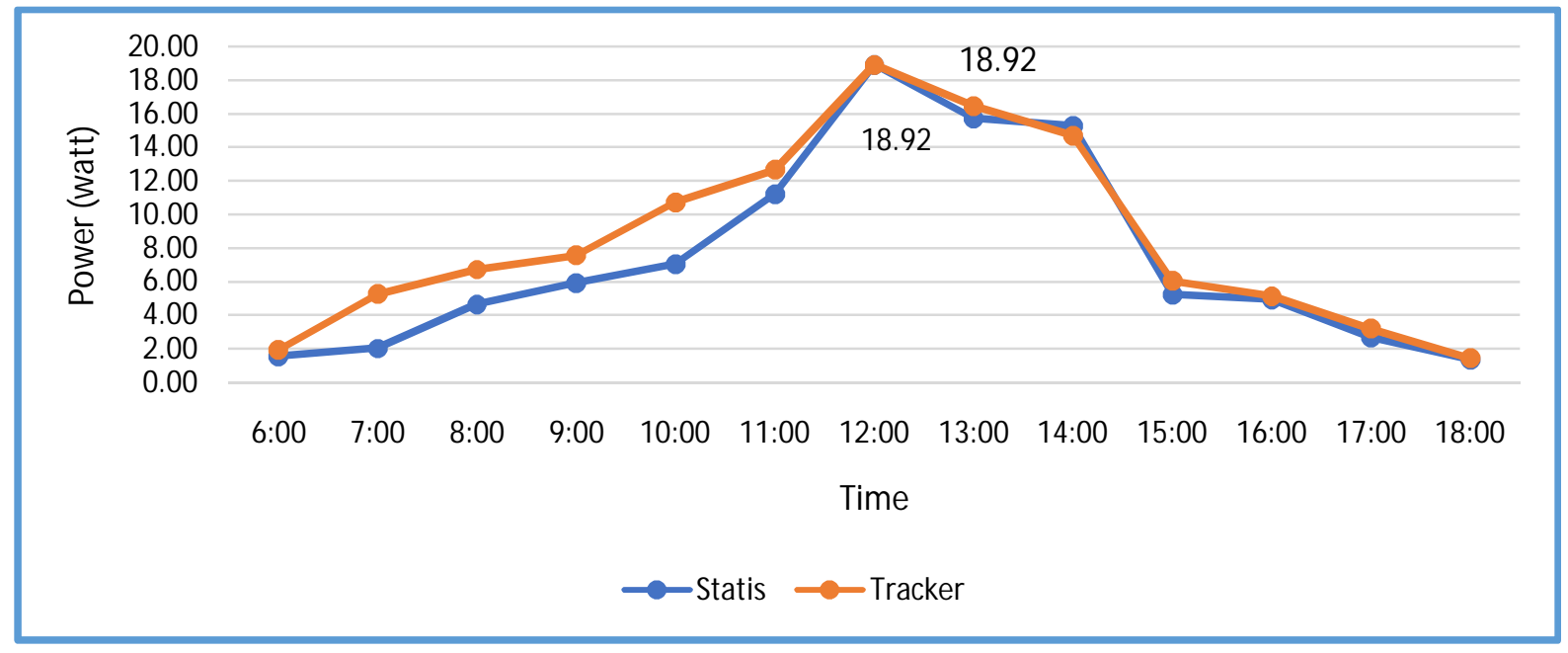

Figure 3: Performance of Solar Panel with Solar Tracking System

This solar tracker made in this study consists of the top, middle and bottom parts. The top is a solar cell that was supported by aluminium rods and equipped with a servo motor as a driver for the vertical rotary axis. The middle part of the tool is a servo motor which functions as a buffer as well
In this test the solar tracker and solar cell static stand side by side and parallel to get the sun's intensity from the same height. Static solar cells positioned at an angle of $45^{\circ}$. 
Based on the data in Figure 3, increasing energy will be sought from the solar tracker method compared with fixed angel method by using the equation below.

$$
\% \text { Energy Gain }=\frac{\Sigma \text { P Solar Tracker }-\Sigma \text { P Static Solar Cell }}{\Sigma P \text { Static Solar Cell }} \times 100 \%
$$

The percentage of energy gain were obtained and tabulated in Table 1.

Table 1: Energy Gain from the Testing

\begin{tabular}{|c|c|c|c|}
\hline Time & $\begin{array}{c}\text { Sum of Solar } \\
\text { Tracker Power } \\
\text { (Watt) }\end{array}$ & $\begin{array}{c}\text { Sum of Static } \\
\text { Solar Cell Power } \\
\text { (Watt) }\end{array}$ & $\begin{array}{c}\text { Energy Gain } \\
\text { (\%) }\end{array}$ \\
\hline Day 1 & 110.65 & 96.58 & $14.57 \%$ \\
\hline Day 2 & 111.88 & 99.45 & $12.49 \%$ \\
\hline Day 3 & 91.41 & 76.62 & $19.29 \%$ \\
\hline Day 4 & 90.61 & 81.55 & $11.17 \%$ \\
\hline Day 5 & 90.55 & 83.10 & $8.96 \%$ \\
\hline
\end{tabular}

\section{CONCLUSSION}

The solar tracking research has done. Detailed comparative performance study of two types of solar tracking system, static and dual-axis has been carried out. It can be concluded that the power obtained from the solar tracker ishigher than static solar panel. The most significant power increase by comparing the tracker and static solar cell is $19.29 \%$, while the lowest power increase is only $8.96 \%$.

\section{ACKNOWLEDGEMENT}

Thank you for Lembaga Penelitian dan Pengabdian kepada Masyarakat (LPPM) Universitas Nasioal and my colleagues at Faculty of Engineering and Science, Universitas Nasional, Jakarta, Indonesia.

\section{REFERENCES}

1. Hidayanti F., Santoso H. H., and Amalia D. Induction Measurement of Extra High Voltage Air Duct. International Journal of Emerging Trends in Engineering Research. 8(4), 1424 - 1427. 2020. https://doi.org/10.30534/ijeter/2020/78842020

2. Hidayanti F., Extraction of Limonite Nickel Ore of Tanjung Buli, Halmahera by Coal Roasting and Acid Leaching. International Journal of Mechanical and Production Engineering Research and Development. 10(2), 513 - 522. 2020.

3. Hidayanti F., Development of Mercury Film Electrode for Cadmium Ion Determination using Voltammetry. International Journal of Advanced Science and Technology. 29(03), 5156 - 5163. 2020.

4. Kabir, E., Kumar, P., Kumar, S., Adelodun, A. A., and Kim, K. H. Solar energy: Potential and future prospects. Renewable and Sustainable Energy Reviews, 82, 894-900. 2018.

https://doi.org/10.1016/j.rser.2017.09.094

5. Hidayanti F., Wati E.K., and Miftahudin M. F. Design of Energy Harvesters on Motorcycle Exhaust using Thermoelectric Generator for Power Supply Electronic Device. International Journal of Renewable Energy Research. 10(1), 251 - 259. 2020.

6. Hidayanti F., Wati E.K., and Akbar H. Energy Harvesting System Design for Converting Noise into Electrical Energy. International Journal of Advanced Science and Technology. 29(03), 4791 - 4802. 2020.

7. Hidayanti F., Rahmah F., and Wiryawan A. Design of Motorcycle Security System with Fingerprint Sensor using Arduino Uno Microcontroller. International Journal of Advanced Science and Technology. 29(05), 4374 - 4391. 2020.

8. Hidayanti F., Rahmah F., and Sahro A. Mockup as Internet of Things Application for Hydroponics Plant Monitoring System. International Journal of Advanced Science and Technology. 29(05), 5157 5164.2020.

9. Hidayanti F., Rahmah F., and Septratama S. Design of Single-Axis Solar Tracker based on Arduino Uno Microcontroller. International Journal of Emerging Trends in Engineering Research. 8(4), 983 - 986. 2020. https://doi.org/10.30534/ijeter/2020/07842020

10. Hidayanti F., Rahmah F., and Agusto J. Design of Solar Tracker on Solar Panel with Fresnel Concentrator". International Journal of Advanced Science and Technology. 29(05), 1014 - 1025.2020.

11. Demirbaş, A., Global Renewable Energy Resources.Energy sources, 28(8): p. 779-792.2006. https://doi.org/10.1080/00908310600718742

12. Alrikabi, N., Renewable Energy Types.Journal of Clean Energy Technologies, 2(1): p. 61-64.2014.

13. Xie, W. T., Dai, Y. J., Wang, R. Z., and Sumathy, K. Concentrated Solar Energy Applications using Fresnel Lenses: A review. Renewable and Sustainable Energy Reviews, 15(6), 2588-2606.2011.

14. Adamo, F., Attivissimo, F., Di Nisio, A., Lanzolla, A. M. L., and Spadavecchia, M. Parameters Estimation for AModel of Photovoltaic Panels. In XIX IMEKO World Congress Fundamental and Applied Metrology, Lisbon, Portugal (pp. 6-11). September, 2009.

15. Afarulrazi, A. B., Utomo, W. M., Liew, K. L., and Zarafi, M. Solar Tracker Robot using Microcontroller. In 2011 International Conference on Business, Engineering and Industrial Applications (pp. 47-50). IEEE.June, 2011. https://doi.org/10.1109/ICBEIA.2011.5994256

16. Bawa, D. and C. Patil, Fuzzy Control based Solar Tracker using Arduino Uno.International Journal of Engineering and Innovative Technology, 2(12): p. 179-187.2013.

17. Dhanabal, R., Bharathi, V., Ranjitha, R., Ponni, A., Deepthi, S., and Mageshkannan, P. Comparison of Efficiencies of Solar Tracker Systems with Static Panel Single-Axis Tracking System and Dual-Axis 
Fitria Hidayanti et al., International Journal of Emerging Trends in Engineering Research, 8(6), June 2020,2631 - 2634

Tracking System with Fixed Mount. International journal of engineering and technology, 5(2), 1925-1933.2013.

18. Chaurey, A. and T.C. Kandpal, Assessment and Evaluation of PV based Decentralized Rural Electrification: An Overview.Renewable and Sustainable Energy Reviews. 14(8): p. 2266-2278. 2010. https://doi.org/10.1016/j.rser.2010.04.005 